\title{
C11orf95/RELA Fusion Protein
}

National Cancer Institute

\section{Source}

National Cancer Institute. C110rf95/RELA Fusion Protein. NCI Thesaurus. Code C129354.

A fusion protein encoded by the C11orf95/RELA fusion gene. This protein is comprised of the $\mathrm{N}$-terminal domain of uncharacterized protein $\mathrm{C} 11$ orf95 fused to most of the transcription factor p65 protein, including the transactivation domain. 